\title{
Fertilization and Application of Different Biochar Types and their Mutual Interactions Influencing Changes of Soil Characteristics in Soils of Different Textures
}

\author{
Vladimír Šimanský' ${ }^{*}$, Dušan Šrank'1, Jerzy Jonczak², Martin Juriga' \\ 1 Department of Soil Science, Faculty of Agrobiology and Food Resources, Slovak University of Agriculture, \\ Tr. A. Hlinku 2, 94976 Nitra, Slovakia \\ 2 Department of Soil Environment Sciences, Faculty of Agriculture and Biology, Warsaw University of Life \\ Sciences SGGW, ul. Nowoursynowska 159, building no. 37, 02-776 Warszawa, Poland \\ * Corresponding author's e-mail: vladimir.simansky@uniag.sk
}

\begin{abstract}
If we want to develop farming on soil effectively and ecologically, we have to know the soil characteristics, the reasons for the potential low fertility and the ways how to eliminate them. Only this approach allows the rational utilization of the soil fund and achievement of the high effectiveness of the costs needed for the stabilization and increase of fertility and land capability. Recently, many scientific teams have focused their attention on the biochar, a lot of recommendations have been published which are dealing with its application into soil. However, the principal attention has been drawn to the impact of biochar on the particular soils and under the particular conditions. Far less information has been presented about the mutual interactions between the further significant agronomical factors in the combination with biochar. In this primary study, we analyze two new experiments established in the southwest part of Slovakia at the 1 Dolná Streda (sandy soil) and 2 Vel'ké Ul'any (loamy soil) Localities. We discussed (1) the impact of the individual factors on the changes of soil characteristics, and (2) the impact of the individual interactions, such as: soil class - fertilization - biochar on the changes of the soil characteristics. The results indicated that the most significant factor, which influences the monitored soil parameters, is the soil class. The fertilization proved to be a factor which has a negative impact on the humus parameters; on the other hand, it improved the soil sorption. Biochar increased the content of the organic substances in soil and also its environmental effect of retention and immobilization of harmful elements and its positive effect on the soil structure was indicated. The highest frequency of the interactions between the monitored parameters related to the changes of soil characteristics was recorded in the combination fertilization $\mathrm{x}$ biochar, and also the soil class $\mathrm{x}$ fertilization $\mathrm{x}$ biochar.
\end{abstract}

Keywords: soil management; Effeco; soil organic matter; physical characteristics; soil nutrient regime; soil sorption

\section{INTRODUCTION}

Along with the climate change and related global warming on the Earth, the organic soil substances and sequestration of organic carbon in soil emerge as one of most effective mitigative measures [Lal 2004]. The organic ratio is an inseparable part of soils, which despite its tiny proportion (in the soils of the temperate climatic zone $0.4-10 \%$ ) compared with the mineral section, has the significant impact on the soils development, the existence of soil organisms, and consequently on the soil fertility. The organic soil substance fulfils several fundamental functions such as: soil formation and development [Šimanský et al. 2018], physical [Polláková et al. 2018], nutritional [Ibrahim and Ramadan 2015], chemical [Peretyazhko and Sposito 2006], biological [Olivares et al. 2015] and environmental [Aijun et al. 2006]. Greenland et al. [1975] stated that the physical properties, and the related optimal conditions for plant growth and development, are being formed in the soil medium with the content of organic substance more than $2 \%$, and which is humified well. While defining the parameters of the most fertile soil also Hraško and Bedrna [1988] claimed that the content of the organic substances in fertile soil should not have 
lower than $2 \%$ in depth $0.3 \mathrm{~m}$ and the quality of humus should be $1-3$, evaluated via the proportion CHA:CFA (carbon of humic acids to carbon of fulvic acids).

In Slovakia, the content of organic substance, expressed through the organic $\mathrm{C}$, ranks in the interval from 0.6 to $3 \%$ [Zaujec et al. 2009]. However, the content of $\mathrm{C}$ in the particular soil types is different. The average content of $\mathrm{C}$ was determined in Chernozems, Luvisols, Mollic Fluvisols, Albeluvisols, Rendzic Leptosols, Fluvisols and Cambisols 1.55, 1.24, 2.34, 1.70, 2.87, 1.60 and $2.48 \%$, respectively [Linkeš et al. 1997]. The content of organic C in Slovakian soils is not sufficient and the latest results of the partial monitoring - Soil (the previous 5 years) showed that the content of $\mathrm{C}$ has increased slightly in the soil types such as: Fluvisols, Mollic Fluvisols, Chernozems, Rendzic Leptosols and Podzols, on the contrary, it has decreased in Cutanic Luvisols, Haplic Planosols and Regosols [Kobza et al., 2017]. As the decline of organic carbon in soils can result in the decrease of soil quality, it was essential to fix the limiting (threshold) values of $\mathrm{C}$ content in the particular regions. On the basis of the soil monitoring results in Slovakia, the limiting values of $\mathrm{C}$ were fixed for the particular soil types of arable soils in Slovakia: Stagnisols, Luvisols and Regosols $>1-1.5 \% \mathrm{C}_{\mathrm{T}}$; Fluvisols, Cambisols, Chernozems and Rendzic Leptosols $>1.51-2 \% \mathrm{C}_{\mathrm{T}}$; Mollic Fluvisols $>2 \% \mathrm{C}_{\mathrm{T}}$.

In the natural ecosystems and also in agro-ecosystems, the primary sources of organic substance are plant, animal and microbial residues along with the products of their metabolism. From the aspect of quantity, the largest source is the afterharvest and root residues of cultivated crops. In the agro-ecosystems, even the optimal cropping pattern is not able to fully supply the loss substitution of the organic matters in soil. Every year, the arable soil loses (by mineralization of organic matters and erosion) 2.5-4 t (sometimes 6-10 t) of the soil organic substances per 1 ha of soil. The root and after-harvest residues compensate these losses on average by $2-3 \mathrm{t}(50-60 \%)$. The remaining $40-50 \%$ has to be supplied into soil in the form of the secondary organic fertilizers [Jurčová and Bielek 1997]. The most frequently used secondary sources of the organic substances applied into soil are: manure, liquid manure, dung water, intercrops, green manuring. In practice, the following commercial composts are also used: crushed domestic waste, sludge from sewage clarification plant, wastes from food-stuff industry, sawdust, hammer-milled bark and other organic wastes. However, with these composts it is necessary to control their chemical composition in advance, predominantly the content of heavy metals and organic pollutants, which must not exceed the limiting amounts.

The balanced and positive result is the consequence of the application of the high doses of the quality organic fertilizers and concurrent application of after-harvest residues. Thus, in order to secure and maintain the bioenergetic potential and natural fertility of our soils it is essential to supply the sufficient inputs of quality sources of organic matters, either in the form of the plant residues or the quality organic fertilizers. The plant resisues are irreplaceable for soils, as there is the shortage of other additional sources of organic matters, and the production of the traditional organic fertilizers is low and constantly falling in comparison with other EU coutries, such as Denmark and Holland [Green report 2014]. In spite of this fact, the agricultural practice still underestimates the significance of the organic substances in soils of the Slovak Republic (SR). The evidence is the continual decline (predominantly because of the economic reasons) of the animal production which is associated with the production of organic fertilizers. Similarly - and even more alarming situation occurs in many agricultural companies in the SR, which were forced to solve their negative economic situation by selling the after-harvest residues. It did not contribute to solving the deficit of the organic substances in soils in any way. The deficiency of organic fertilizers and removal of the plant residues leads definitely to the decrease of organic carbon contents in soils and the degradation of physical, chemical and biological characteristics of soils and their functions [Rao et al. 2017].

It is possible to find the partial solution by using other additional sources of organic matters, e.g. processing of the biodegradable waste from households under the economically favourable conditions. Many scrapyards in cities and villages in the SR have to solve the problem of the accumulated biological waste (grass, foliage, branches) because they do not have the technology for its processing. However, it is not necessary to devise new ways - it is enough to look into the past. The problem could be solved by composting or by processing biomass through carbonization, which considerably lowers the quantity 
of biological waste. If the emerged by-product is formed by pyrolysis of biological waste, and does not contain any dangerous and harmful to health matters, then it can be applied into soil and bring significant benefits. In order to start up and achieve the economic effectiveness of this process, this measure would require the attention of the authorized bodies or ministries of the SR.

There are many examples in the history where people solved these problems according to the above-mentioned principle. They applied the organic material, like household leftovers, excrements, waste biomass along with the residues of unburned wood straight into soil, or people gathered them at the certain places, which resulted in the formation of soils of higher fertility. The most well-known example from the scientific literature is the formation of chernozems by a man 8.000 years ago, which are called Terra Preta de Índio, created by the Amazonian Indians [Glaster 2007]. Of course, there are many more examples from the past and from the whole world, which are collected in the publication "Biochar-management" [Lehman and Joseph 2015]. The Terra Preta de Índio phenomenon has become an inspiration for many scientific teams of the recent twenty years. Their attention has been focused on the production of biochar which is consequently applied into soil as a potential conditioner of soil properties. Many studies, which are related to the different soil-climatic zones and parts of the world, pointed out the positive effect of biochar on improvement of soil chemistry [Mia et al. 2017, Beusch et al. 2019, El-Naggara et al. 2019], the improvement of biological [Lehmann et al. 2011], and also the physical characteristics of soils [Biederman and Harpole 2013, Ajayi and Horn 2016, Igalavithana et al. 2017]. Apart from the impact on the soil properties, the positive effects were detected on the yield increase of cultivated crops [Biederman and Harpole 2013, El-Naggar et al. 2018]. Indeed, negative or no effects on the soil characteristics and crop yields were also recorded [Jeffery et al. 2017]. However, the benefits of biochar prevail unambiguously. The positive effects were monitored mostly in the sandy soils [Laghari et al.
2015, Šimanský et al. 2019]. In the previous studies of this scientific field, the studies which deal with the biochar effect itself, or its combinations with other fertilizers on the soil parameters and yields of cultivated crops, prevail. There is much less information about the mutual interactions between other significant agronomical factors in the combination with biochar. Therefore, this paper is targeted at the evaluation (1) the impact of the individual factors on the changes of soil properties, and (2) the impact of the particular interactions, such as soil classes - fertilization - biochar, on the changes of the soil properties.

\section{MATERIAL AND METHODS}

\section{Characteristics of locations}

The experiments were established in the south-western part of Slovakia at the 1 Dolná Streda $\left(48^{\circ} 15^{\circ} 16.6^{\prime \prime} \mathrm{N} 17^{\circ} 43^{\circ} 02.7^{\prime \prime} \mathrm{E}\right)$ and 2 Vel'ké Ul'any (48 $\left.09^{\circ} 11.5^{\prime \prime} \mathrm{N} 17^{\circ} 34^{\prime} 57.6^{\prime \prime} \mathrm{E}\right)$ localities. The average annual temperature is $9-10^{\circ} \mathrm{C}$ and the average annual rainfall totalls fluctuate from 520 to $600 \mathrm{~mm}$ at both localities. In Dolná Streda, the experiment was established on the sandy Haplic Arenosol (Arenic, Calcic) and in Vel'ké Ul'any the trial was established on the loamy Vermic Chernozem (Mollic, Loamic). The soil characteristics of both soils before establishing the experiment are indicated in Table 1. Prior to the experiment, these soils were used for the intensive agricultural production and were cultivated using the traditional techniques, depending on the particular grown crop in a certain period.

\section{Characteristics of experiments}

The experiment in the locality Dolná Streda was established in autumn 2017. In total, 10 treatments were created. Their description is given in the Table 2. The area of one plot was $810 \mathrm{~m}^{2}$ and the protective belt of $1 \mathrm{~m}$ was left between the individual plots. The experiment was established by the method of long segments. Before the experiment was established, the preceding

Table 1. Soil characteristics before experiment establishing

\begin{tabular}{|c|c|c|c|c|c|c|c|c|}
\hline \multirow{2}{*}{ Locality } & sand & silt & clay & $\mathrm{C}_{\text {org }}$ & $\mathrm{N}$ & $\mathrm{P}$ & $\mathrm{K}$ & \multirow{2}{*}{$\mathrm{pH}$} \\
\hline & \multicolumn{4}{|c|}{$\%$} & \multicolumn{3}{|c|}{$\mathrm{mg} \mathrm{kg}^{-1}$} & \\
\hline Dolná Streda & 81.9 & 10.5 & 7.64 & 0.97 & 1,323 & 175 & 165 & 7.60 \\
\hline Vel'ké Ul'any & 38.5 & 47.8 & 13.7 & 1.56 & 966 & 129 & 255 & 7.78 \\
\hline
\end{tabular}


crop was durum wheat. In autumn 2017, the individual types and doses of biochar were applied into soil in depth $15 \mathrm{~cm}$ by disk tillage. During the whole period of experiment the minimizing system of soil cultivation will be used here, i.e. the disk tillage to the depth of $15-18 \mathrm{~cm}$. In spring 2018 , before sowing of sunflower, the urea was applied into soil in dose of $100 \mathrm{~kg} \mathrm{ha}^{-1}$ in some treatments (Table 2).

The experiment in the Vel'ké Ul'any locality was established in spring 2018, and similarly, 10 treatments were created (Table 2). The area of one plot was $25 \mathrm{~m}^{2}$ and the protective belts were left between the plots. The experiment was established using the method of random arrangement with the double repetition. The preceding crop was carrot. Before planting green pepper (crop in 2018), the biochar was applied into soil (in depth $10-12 \mathrm{~cm}$ ) and also granulated fertilizer Italpollina. The soil is cultivated in the traditional way, i.e. in autumn it is tilled to the depth of $20 \mathrm{~cm}$ and in spring it is consequently prepared by tiller, and depending on the grown vegetable also the mechanical hoe can be used in combination with the chemical weed killing. During the vegetation period of green pepper growing in 2018, the drop irrigation was applied 3 times in total (application dose $=$ saturation of soil by water to $80 \%$ of field water capacity).

Two types of biochar were tested, labelled with the Effeco 50:50 and Effeco 33:33:33 trade mark from the company Zdroje Zeme, ag., which develops biocarbon substrates. Effeco 50:50 is the biochar mixed with the dried sheep manure in the proportion $1: 1$ and it contains $43 \%$ of total organic carbon, $1.2 \%$ total N, $0.49 \% \mathrm{P}$ and $24.6 \%$ $\mathrm{K}$, and its $\mathrm{pH}$ is 8.18 . Effeco $33: 33: 33$ is the biochar mixed with the dried sheep manure and the separate from the biogas station (original substance cattle manure) in the 1:1:1 proportion and it contains $45.4 \%$ of total organic carbon, $1.3 \%$ of total $\mathrm{N}, 0.79 \% \mathrm{P}$ and $15.5 \% \mathrm{~K}$, and its $\mathrm{pH}$ is 8.44 . The content of risk elements in both types of biochar does not exceed the limit rates, which are set by the regulation 577/2005 The regulation determines the manure types, composition, packaging and labelling of fertilizers, analytical methods, fertilizers testing, risk elements, their limit rates for the particular groups of fertilizers, tolerance and limit rates for organic fertilizers and the Act 220/2004 of protection and utilization of agricultural soil (in the Slovak Republic). Both types of biochar are granulated into the shape of roll with the size of about $2 \times 1 \times 1 \mathrm{~cm}$.

\section{Sampling and analysis of soil samples}

In autumn 2018, the soil samples were taken from both experiments and all treatments in order to determine the physical and chemical characteristics. The soil samples for the determination of hydro-physical properties were taken in the untouched condition and placed into the steel cylinders with the size of $5 \times 6 \mathrm{~cm}$ from two depths, i.e. $0-10 \mathrm{~cm}$ and $10-20 \mathrm{~cm}$. The samples for the assessment of structural condition were taken by means of a spade from the depth $0-20 \mathrm{~cm}$; at the same time, special attention was paid to the preservation of the natural structure of soil. In the laboratory this sample was decomposed along the natural lines of the formed aggregates into smaller clusters and dried at the laboratory temperature. The soil samples for the determination of chemical properties, the parameters of soil

Table 2. Description of experiment treatments

\begin{tabular}{|c|c|}
\hline Dolná Streda & Vel'ké Ul’any \\
\hline 1. Control (no fertilized) & 1. Control (no fertilized) \\
\hline 2. Biochar $50: 50$ at rate of $10 \mathrm{t} \mathrm{ha}^{-1}$ & 2. Biochar $50: 50$ at rate of $10 \mathrm{t} \mathrm{ha}^{-1}$ \\
\hline 3. Biochar $50: 50$ at rate of $20 \mathrm{tha}^{-1}$ & 3. Biochar $50: 50$ at rate of $20 \mathrm{t} \mathrm{ha}^{-1}$ \\
\hline 4. Biochar $33: 33: 33$ at rate of $10 \mathrm{t} \mathrm{ha}^{-1}$ & 4. Biochar $33: 33: 33$ at rate of $10 \mathrm{t} \mathrm{ha}^{-1}$ \\
\hline 5. Biochar $33: 33: 33$ at rate of $20 \mathrm{t} \mathrm{ha}^{-1}$ & 5. Biochar $33: 33: 33$ at rate of $20 \mathrm{t} \mathrm{ha}^{-1}$ \\
\hline 6. Urea at rate of $100 \mathrm{~kg} \mathrm{ha}^{-1}$ & 6. Italpollina $4-4-4$ at rate of $850 \mathrm{~kg} \mathrm{ha}^{-1}$ \\
\hline $\begin{array}{l}\text { 7. Biochar } 50: 50 \text { at rate of } 10 \mathrm{tha}^{-1}+\text { Urea at rate of } \\
100 \mathrm{~kg} \mathrm{ha}^{-1}\end{array}$ & $\begin{array}{l}\text { 7. Biochar } 50: 50 \text { at rate of } 10 \mathrm{t} \mathrm{ha}^{-1}+\text { Italpollina } 4-4-4 \text { at rate of } \\
850 \mathrm{~kg} \mathrm{ha}^{-1}\end{array}$ \\
\hline $\begin{array}{l}\text { 8. Biochar } 50: 50 \text { at rate of } 20 \mathrm{t} \mathrm{ha}^{-1}+\text { Urea at rate of } \\
100 \mathrm{~kg} \mathrm{ha}^{-1}\end{array}$ & $\begin{array}{l}\text { 8. Biochar } 50: 50 \text { at rate of } 20 \mathrm{t} \mathrm{ha}^{-1}+\text { Italpollina } 4-4-4 \text { at rate of } \\
850 \mathrm{~kg} \mathrm{ha}^{-1}\end{array}$ \\
\hline $\begin{array}{l}\text { 9. Biochar } 33: 33: 33 \text { at rate of } 10 \mathrm{t} \mathrm{ha}^{-1}+\text { Urea at rate of } \\
100 \mathrm{~kg} \mathrm{ha}^{-1}\end{array}$ & $\begin{array}{l}\text { 9. Biochar } 33: 33: 33 \text { at rate of } 10 \mathrm{t} \mathrm{ha}^{-1}+\text { Italpollina } 4-4-4 \text { at rate } \\
\text { of } 850 \mathrm{~kg} \mathrm{ha}^{-1}\end{array}$ \\
\hline $\begin{array}{l}\text { 10. Biochar } 33: 33: 33 \text { at rate of } 20 \mathrm{t} \mathrm{ha}^{-1}+\text { Urea at rate of } \\
100 \mathrm{~kg} \mathrm{ha}^{-1}\end{array}$ & $\begin{array}{l}\text { 10. Biochar } 33: 33: 33 \text { at rate of } 20 \mathrm{t} \mathrm{ha}^{-1}+\text { Italpollina } 4-4-4 \text { at rate } \\
\text { of } 850 \mathrm{~kg} \mathrm{ha}^{-1}\end{array}$ \\
\hline
\end{tabular}


sorption complex and soil organic matter were taken from the depth $20 \mathrm{~cm}$. After drying, the samples were crushed and homogenized. The following physical characteristics were determined with the standard methods: the bulk density $\left(\rho_{\mathrm{d}}\right)$, total soil porosity $(\mathrm{P})$, content of non-capillary pores $(\mathrm{Pn})$, capillary absorbsbility $\left(\Theta_{\mathrm{KN}}\right)$, maximal capillar water capacity $\left(\Theta_{\mathrm{MCWC}}\right)$, retention water capacity $\left(\Theta_{\mathrm{RWC}}\right)$ and lento-capillary point $\left(\Theta_{\mathrm{v}}\right)$ [Hrivnáková et al. 2011]. Next, the soil particle-size distribution was determined by means of the pipette method [Hrivňáková et al. 2011], also the fractions of structural aggregates - by dry sieving (fractions: $>7 \mathrm{~mm}, 7-5 \mathrm{~mm}, 5-3 \mathrm{~mm}, 3-1$ $\mathrm{mm}, 1-0.5 \mathrm{~mm}, 0.5-0.25 \mathrm{~mm}$ and $<0.25 \mathrm{~mm}$ ), the fractions of water-stable aggregates - WSA (fractions: $>5 \mathrm{~mm}, 5-3 \mathrm{~mm}, 3-2 \mathrm{~mm}, 2-1 \mathrm{~mm}, 1-0.5$ $\mathrm{mm}, 0.5-0.25 \mathrm{~mm}$ and $<0.25 \mathrm{~mm}$ ) by Baksheev method [Hraško et al. 1962]. On the basis of the determined fractions of structural and waterstable aggregates, the mean weight diameter for dry sieving (MWDd) and water-stable aggregates (MWDw), vulnerability of soil structure (Kv) and structure coefficient $(\mathrm{K})$ were calculated according to the equations $1-4$.

$$
M W D d=\sum_{n=1}^{n} x i w i
$$

where: $i-1,2,3 \ldots . n$

$n$ - corresponds to each determined fraction

$x i-$ weighted average of the size fraction $w i$ - percentage of sample on sieve

$$
M W D w=\sum_{n=1}^{n} x i W S A
$$

where: $i-1,2,3 \ldots . \mathrm{n}$

$n$ - corresponds to each determined fraction

$x i$ - weighted average fraction size $(\mathrm{mm})$

$W S A$ - water-resistant aggregates

$$
\mathrm{K}_{\mathrm{v}}=\frac{\mathrm{MWDs}}{\mathrm{MWDm}}
$$

where: $M W D d-$ mean weight diameter of macro-aggregates for dry sieving $(\mathrm{mm})$

$M W D W$ - mean weight diameter of waterstable aggregates $(\mathrm{mm})$

$$
\mathrm{K}=\frac{A}{B}
$$

where: $A-$ weight of aggregates from $0.25-7.0 \mathrm{~mm}$

$B$ - weight of addition of aggregates $<0.25 \mathrm{~mm}$ and $>7 \mathrm{~mm}$

The following chemical characteristics were determined in the soil samples: soil $\mathrm{pH}-\mathrm{pH}$ in $\mathrm{H}_{2} \mathrm{O}$ and $\mathrm{pH}$ in 1 mol.dm ${ }^{-3} \mathrm{KCl}$ - potentiometrically [Hrivňáková et al. 2011], the soil sorption parameters [Hrivňáková et al. 2011], the content of soil organic carbon $\left(\mathrm{C}_{\text {org }}\right)$ - oxidometrically [Dziadowiec and Gonet 1999a], the group composition of humus substances [Dziadowiec and Gonet 1999b]. The contents of total N and S were defined using the Elementar Vario MacroCube analyzer. The total contents of $\mathrm{K}, \mathrm{Ca}, \mathrm{Mg}, \mathrm{Fe}$, $\mathrm{Mn}, \mathrm{Cr}, \mathrm{Cu}, \mathrm{Ni}$ and $\mathrm{Zn}$ were analyzed after the decomposition of ashed samples by aqua regia. The content of total $\mathrm{P}$ was estimated spectrophotometrically as molybdenum blue, while the rest of the elements were analyzed with the method AAS (Perkin Elmer AA 2100). The contents of available $\mathrm{P}, \mathrm{K}, \mathrm{Ca}, \mathrm{Mg}, \mathrm{Cu}, \mathrm{Mn}, \mathrm{Ni}$ and $\mathrm{Zn}$ forms were determined after the extraction of samples in the Mehlich III solution. The content of available $\mathrm{P}$ in the extract was analyzed spectrophotometrically as molybdenum blue, while the rest of elements were analyzed with the AAS method (Perkin Elmer AA 2100).

Consequently, the acquired results were evaluated by multi-analysis variation. The average rates of the monitored factors (soil class, fertilization, biochar) were estimated by LSD test with the minimal level of significance $p \leq 0.05$. A correlation analysis was applied to study the relationships between the total and available macro- and micro-element.

\section{RESULTS AND DISCUSSION}

\section{Soil pH and parameters of soil sorption complex}

The values of soil $\mathrm{pH}$ in $\mathrm{H}_{2} \mathrm{O}$ and soil $\mathrm{pH}$ in $\mathrm{KCl}$ were in the interval from 7.23 to 7.94 and from 7.49 to 8.12 , respectively, and they were significantly dependent on the soil class and biochar application (Table 3). The soil $\mathrm{pH}$ is influenced considerably by the parrent material [Šimanský et al. 2018]; however, it also depends on the way of soil utilization or cultivation [Šimanský et al. 2008]. Both monitored soil classes contained carbonates, which was also reflected in the level of soil $\mathrm{pH}$; 
it was slightly alkaline, or even alkaline. A higher soil $\mathrm{pH}$ was detected in the loamy soil than the sandy soil (on average, by $6 \%$ ). The difference between the fertilized and non-fertilized soil was not significant. In both soil classes, the statistically significant difference was observed after the biochar application. Both types of the tested biochar significantly increased the soil $\mathrm{pH}$ in $\mathrm{H}_{2} \mathrm{O}$ and also soil $\mathrm{pH}$ in $\mathrm{KCl}$. Several studies have been already published, which approved the liming effect of the applied biochar, predominantly in acid soils [Horák et al. 2017, Teutscherova et al. 2017, Šimanský et al. 2018a]. It is caused mostly by the properties of biochar itself, which is alkaline (in our case). Biochar contains the basic cations which can react with $\mathrm{H}^{+}$and in this way, $\mathrm{pH}$ is increased and soil acidity is decreased [Novak et al. 2009]. In total, the average difference between soil $\mathrm{pH}$ in $\mathrm{H}_{2} \mathrm{O}$ and soil $\mathrm{pH}$ in $\mathrm{KCl}$ was -0.22 or $\Delta \mathrm{pH}$ [Hanes 1999], which indicates that anions dominate on the surface of the soil particles. It increases the sorption of anions in both soil classes, in both systems of fertilization also owing to the application of biochar (Table 3). The statistically significant interactions were detected with soil $\mathrm{pH}$ in the combination fertilization $\times$ biochar, but also of all monitored factors. The effect of fertilization in combination with biochar depends on the type of fertilization and also the soil class. For example, the application of the mineral fertilizers with the physiologically acid effect can inhibit the alkaline effect of biochar, and on the contrary, the organic fertilization can foster this effect. The soil class has a considerable impact on the changes of soil $\mathrm{pH}$ through the different parrent materials [Šimanský et al. 2018].

The parameters of sorption are indicated in the Table 3. The statistically significant differences were detected as a result of the different soil class and fertilization. Soil sorption is influenced considerably by the soil texture and the content of organic matter in soil [Szombathová 2010, Šimanský et al. 2018]. While comparing the different textured soils, the difference between them was evident in the sorptive parameters. A higher hydrolitic acidity $(\mathrm{H})$ was found in the sandy soil than in the loamy soil. Severalfold higher values of sum of basic cations (SBC), cation exchange capacity (CEC) and base saturation (Bs) occurred in the loamy soil than in the sandy soil. Fertilization can have an either positive or negative impact on sorption, depending on the application of fertilizers of different form or quality. For instance, one-sided application of mineral fertilizers can worsen the soil sorption via the decomposition of clay minerals or mineralization of organic substances. The application of farmyard manure improves the soil sorption, especially the humus

Table 3. Soil pH and parameters of sorption complex

\begin{tabular}{|c|c|c|c|c|c|c|}
\hline \multirow{2}{*}{ Factors } & \multirow{2}{*}{$\mathrm{pH}_{\mathrm{H} 2 \mathrm{O}}$} & \multirow{2}{*}{$\mathrm{pH}_{\mathrm{KCl}}$} & $\mathrm{H}$ & SBC & CEC & \multirow{2}{*}{$\begin{array}{l}\text { Bs } \\
\%\end{array}$} \\
\hline & & & \multicolumn{3}{|c|}{$\mathrm{mmol} \mathrm{kg}^{-1}$} & \\
\hline \multicolumn{7}{|l|}{ Soil class } \\
\hline Sandy & $7.43 a$ & $7.65 a$ & $3.00 \mathrm{~b}$ & $51.8 \mathrm{a}$ & $53.9 a$ & $93.7 a$ \\
\hline Loamy & $7.84 b$ & $8.04 b$ & $2.54 a$ & $492.5 b$ & $495.1 \mathrm{~b}$ & $99.5 b$ \\
\hline$P$-value & $* * *$ & $* * *$ & $* * *$ & $* * *$ & $* * *$ & $* * *$ \\
\hline \multicolumn{7}{|l|}{ Fertilization } \\
\hline No fertilization & $7.62 a$ & $7.82 a$ & $3.03 b$ & $265.9 a$ & $268.9 a$ & $95.8 a$ \\
\hline Fertilization & 7.66a & $7.88 a$ & $2.55 a$ & $278.4 b$ & $280.1 \mathrm{~b}$ & $97.3 \mathrm{~b}$ \\
\hline$P$-Value & n.s. & n.s. & $* * *$ & * & ** & $* *$ \\
\hline \multicolumn{7}{|l|}{ Biochar } \\
\hline Control & $7.55 a$ & $7.78 \mathrm{a}$ & $2.81 \mathrm{ab}$ & $274.6 a$ & $276.2 a$ & $96.4 a$ \\
\hline Effeco 33:33:33 & $7.68 b$ & $7.88 \mathrm{~b}$ & $2.90 \mathrm{~b}$ & $273.8 a$ & $276.7 a$ & $96.9 a$ \\
\hline Effeco 50:50 & $7.68 b$ & $7.88 \mathrm{~b}$ & $2.67 a$ & $267.9 a$ & $270.6 a$ & $96.5 a$ \\
\hline$P$-value & ${ }^{* * *}$ & $* *$ & ${ }^{*}$ & n.s. & n.s. & n.s. \\
\hline \multicolumn{7}{|l|}{ INTERACIONS P-values } \\
\hline Soil class $\times$ Fertilization & n.s. & 0.4235 & 0.0916 & ** & * & ** \\
\hline Soil class $\times$ Biochar & n.s. & 0.0892 & $\star * \star *$ & n.s. & n.s. & n.s. \\
\hline Fertilization $\times$ Biochar & $* * *$ & * & $* * *$ & n.s. & n.s. & ${ }^{*}$ \\
\hline Soil class $\times$ Fertilization $\times$ Biochar & *** & * & $* * *$ & n.s. & n.s. & * \\
\hline
\end{tabular}

n.s. - non-significant; ${ }^{*} \mathrm{P}<0.05 ; * * \mathrm{P}<0.01 ; * * * \mathrm{P}<0.001$

Different letters $(a, b)$ between lines indicate that treatment means are significantly different at $\mathrm{P}<0.05$ according to LSD test. 
sorption [Šimanský and Polláková 2014]. In our experiment, fertilization had a positive impact and decreased $\mathrm{H}$; on the other hand, it increased $\mathrm{SBC}, \mathrm{CEC}$ and Bs. The interesting fact is that the application of both types of biochar did not have a statistically significant effect on the level of sorption in spite of the information described in the scientific literature about the positive effect of its application on the improvement of the sorption characteristics of soils [Heitkötter and Marschner 2015], through its high active surface and large volume of pores [Chintala et al. 2014]. This can be attributed to the the negative charge of soil particles (average $\Delta \mathrm{pH}=-0.22$ ) and also the because the biochar applied into soils of the neutral or slightly alkaline $\mathrm{pH}$ often has free carboxyl groups on surface [Lehmann and Joseph 2015]. On the surface of the soil particles or biochar particles, the anion exchange was carried out, which is considerably lower than the exchange of cations and can totally influence the soil sorption [Hanes 1999, Zaujec et al. 2008]. The statistically significant interactions of the change $\mathrm{H}$ were detected in the case of the soil class $\times$ biochar, and also fertilization $\times$ biochar, as well as in the combination of all factors. The SBC and CEC values were statistically significantly influenced only by the interaction of soil class $\times$ fertilization. The values of Bs were statistically significantly influenced by the interaction of soil class $\times$ fertilization, fertilization $\mathrm{x}$ biochar, and also the combination of all monitored factors (Table 3 ).

\section{Content of total and available macro and microelements}

The content of total and available macro and microelements, depending on the monitored factors and their mutual interactions, are presented in the Tables 4 and 5. The contents of total and available macro and microelements were significantly different only in dependence on the soil class. The granular light soils in the SR contain on average lower contents of macronutrients in comparison with the loamy soils [Kováčik 2014, Šimanský et al. 2018], which also corresponds with our findings (Table 4). Fertilization had a statistically significant impact on the content of total $\mathrm{P}, \mathrm{Ca}$ and $\mathrm{Mg}$, and available $\mathrm{Ca}$. As a result of fertilization, the amounts of total $\mathrm{P}, \mathrm{Ca}$, $\mathrm{Mg}$ and available $\mathrm{Ca}$ were higher by $70,3,277$, 860 and $1,386 \mathrm{mg} \mathrm{kg}^{-1}$. The interesting fact is that if the effect of applied types of biochar into both soils was evaluated, the total contents of macronutrients were not statistically significantly changed, where biochar is considered to be an important source of nutrients [Rajkoviak et al. 2012, Šimanský et al. 2019]. However, their

Table 4. Contents of total macro and microelements

\begin{tabular}{|c|c|c|c|c|c|c|c|c|c|c|c|c|}
\hline \multirow{2}{*}{ Factors } & $\mathrm{N}$ & $S$ & $\mathrm{P}$ & $\mathrm{K}$ & $\mathrm{Ca}$ & $\mathrm{Mg}$ & $\mathrm{Fe}$ & $\mathrm{Mn}$ & $\mathrm{Cr}$ & $\mathrm{Cu}$ & $\mathrm{Zn}$ & $\mathrm{Ni}$ \\
\hline & \multicolumn{3}{|c|}{$\mathrm{mg} \mathrm{kg}^{-1}$} & \multicolumn{4}{|c|}{$\mathrm{g} \mathrm{kg}^{-1}$} & \multicolumn{5}{|c|}{$\mathrm{mg} \mathrm{kg}^{-1}$} \\
\hline \multicolumn{13}{|l|}{ Soil class } \\
\hline Sandy & $1388 a$ & $238 a$ & $1271 b$ & $12.1 \mathrm{a}$ & $45.6 a$ & $11.6 a$ & $13.9 a$ & $413 a$ & $21.1 a$ & $14.2 a$ & $45.1 a$ & $21.9 a$ \\
\hline Loamy & $1776 b$ & $414 \mathrm{~b}$ & $1140 a$ & $15.1 \mathrm{~b}$ & $6.19 b$ & $23.6 b$ & $24.5 b$ & $537 \mathrm{~b}$ & $41.6 \mathrm{~b}$ & $30.9 b$ & $59.1 b$ & $32.6 b$ \\
\hline$P$-value & $* * *$ & $* * *$ & $* \star *$ & $* \star *$ & $\star * \star *$ & $* \star \star$ & $* * *$ & $* * *$ & $* \star *$ & $\star * \star *$ & $\star * \star *$ & $* * *$ \\
\hline \multicolumn{13}{|l|}{ Fertilization } \\
\hline No fertilization & $1606 a$ & $341 a$ & $1171 a$ & $13.6 a$ & $52.1 \mathrm{a}$ & $17.2 a$ & $19.1 \mathrm{a}$ & $472 a$ & $30.5 a$ & $22.4 a$ & $46.1 a$ & $24.9 a$ \\
\hline Fertilization & $1558 a$ & $312 a$ & $1241 b$ & $13.6 \mathrm{a}$ & $55.4 \mathrm{~b}$ & $18.0 \mathrm{~b}$ & $19.3 a$ & $478 a$ & $32.1 \mathrm{~b}$ & $22.8 a$ & $58.0 \mathrm{~b}$ & $29.6 b$ \\
\hline$P$-Value & n.s. & n.s. & * & n.s. & * & ** & n.s. & n.s. & $* * *$ & n.s. & *** & * \\
\hline \multicolumn{13}{|l|}{ Biochar } \\
\hline Control & $1625 a$ & $328 a$ & $1235 a$ & $13.5 \mathrm{a}$ & $53.6 a$ & $17.5 \mathrm{a}$ & 19.3a & $473 a$ & $31.8 b$ & $23.1 \mathrm{a}$ & $62.6 \mathrm{~b}$ & $27.6 a$ \\
\hline Effeco 33:33:33 & $1549 a$ & $317 a$ & $1200 a$ & $13.7 \mathrm{a}$ & $53.2 a$ & $17.5 a$ & $19.2 \mathrm{a}$ & $480 a$ & $30.0 a$ & $22.3 a$ & $47.5 a$ & $28.6 a$ \\
\hline Effeco 50:50 & $1573 a$ & $334 a$ & $1182 a$ & $13.6 \mathrm{a}$ & $54.4 a$ & $17.8 \mathrm{a}$ & $18.9 a$ & $473 a$ & $31.6 b$ & $22.2 \mathrm{a}$ & $46.1 \mathrm{a}$ & $25.6 a$ \\
\hline$P$-value & n.s. & n.s. & n.s. & n.s. & n.s. & n.s. & n.s. & n.s. & $* *$ & n.s. & $* \star *$ & n.s. \\
\hline \multicolumn{13}{|l|}{ INTERACIONS P-values } \\
\hline Soil class $\times$ Fertilization & n.s. & n.s. & n.s. & * & n.s. & * & * & * & *** & *** & n.s. & n.s. \\
\hline Soil class $\times$ Biochar & n.s. & n.s. & n.s. & n.s. & n.s. & n.s. & ${ }^{*}$ & n.s. & $* * *$ & $* * *$ & n.s. & n.s. \\
\hline Fertilization $\times$ Biochar & $* * *$ & * & n.s. & *** & $* * *$ & $* * *$ & $* * *$ & $* * *$ & $* * *$ & $* * *$ & *** & n.s. \\
\hline $\begin{array}{l}\text { Soil class } \times \text { Fertilization } \times \\
\text { xBiochar }\end{array}$ & *** & ** & ** & *** & *** & *** & *** & *** & $* * *$ & *** & *** & n.s. \\
\hline
\end{tabular}

n.s. - non-significant; ${ }^{*} \mathrm{P}<0.05 ; * * \mathrm{P}<0.01 ; * * * \mathrm{P}<0.001$

Different letters $(\mathrm{a}, \mathrm{b})$ between lines indicate that treatment means are significantly different at $P<0.05$ according to LSD test. 
availability could be limited considerably by its properties, like its surface area, the sorption capacity itself, through it the nutrients can be kept in soil [Chintala et al. 2014]. Only the applications of Effeco 33:33:33 biochar increased the content of available $\mathrm{Mg}$ in soil in a statistically significant way. The statistically significant interactions on the content of total and available macronutrients were detected in the fertilization $\times$ biochar combination, and also the soil class $\times$ fertilization $\times$ biochar (Tables 4 and 5). The contents of total and available microelements were influenced by the soil class. The average contents of total microelements in soil, such as: $\mathrm{Fe}, \mathrm{Mn}, \mathrm{Cu}, \mathrm{Zn}$ are $10 \%$, $450 \mathrm{mg} \mathrm{kg}^{-1}, 40 \mathrm{mg} \mathrm{kg}^{-1}, 160 \mathrm{mg} \mathrm{kg}^{-1}$ and they are being considerably changed, dependening on the soil class, where - as a rule - the lower contents are recorded in the sandy soils [Kováćik 2014]. In our experiment the fertilization had an essential effect on the contents of total $\mathrm{Cr}, \mathrm{Zn}$ and Ni (total forms were increased significantly as a result of fertilization) and also the availabilty of $\mathrm{Mn}$, $\mathrm{Cu}, \mathrm{Zn}$ and $\mathrm{Ni}$ was increased as a consequence of fertilization (Table 5). Besides, the fertilizers are the important source of microelements, but also some harmful elements, which can be accumulated in soil as a result of fertlizers application and under the favourable conditons their mobility can rise [Vaněk et al. 2013, Kováčik 2014]. The biochar had a statistically significant impact on the decrease of the total contents of $\mathrm{Cr}, \mathrm{Zn}$, and available $\mathrm{Cu}, \mathrm{Zn}$ and $\mathrm{Ni}$, which can be considered as a benefit. These findings approve the fact that the biochar can be used as an important environmental tool, eliminating the content of heavy metals and other harmful matters in soil [Evangelou et al. 2014]. The contents of total $\mathrm{Fe}, \mathrm{Cr}$, $\mathrm{Cu}$ and available $\mathrm{Zn}$ were also statistically significantly changed by the mutual interaction relationships soil class $\times$ fertilization $\times$ biochar. We can see a great benefit in the fact that all contents of microelements were statistically significantly changed by the interaction fertilization $\times$ biochar, because this mutual interaction can be carried out easier than e.g. adjustment of a soil class.

As it is indicated in the Tables 4 and 5, the contents of some total and also available macro and microelements were considerably different than the monitored factors, it could be reflected also in their mutual relations, because in the scientific literature there are the well-known antagonistic and synergetic relations between the individual elements [Vaněk et al. 2013, Zlámalová et al. 2015]. In our study, we observed significant correlations between the content of available and total elements in soil (Table 6). The antagonism was detected between the total $\mathrm{P}$ and available $\mathrm{Ca}$, $\mathrm{Mg}, \mathrm{Mn}, \mathrm{Cu}$ and $\mathrm{Ni}$, similarly, between the total $\mathrm{Ca}$ and available $\mathrm{Fe}$ and $\mathrm{Zn}$, but also between the total $\mathrm{Fe}$ a $\mathrm{Mn}, \mathrm{Cu}$ a Ni. The synergetic relations

Table 5. Contents of available macro and microelements

\begin{tabular}{|c|c|c|c|c|c|c|c|c|c|}
\hline \multirow{2}{*}{ Factors } & $\mathrm{P}$ & $\mathrm{K}$ & $\mathrm{Ca}$ & $\mathrm{Mg}$ & $\mathrm{Fe}$ & $\mathrm{Mn}$ & $\mathrm{Cu}$ & $\mathrm{Zn}$ & $\mathrm{Ni}$ \\
\hline & \multicolumn{9}{|c|}{$\mathrm{mg} \mathrm{kg}^{-1}$} \\
\hline \multicolumn{10}{|l|}{ Soil class } \\
\hline Sandy & $312 b$ & $208 b$ & $5855 a$ & $239 a$ & $363 b$ & $67.1 \mathrm{a}$ & $3.38 a$ & $15.1 b$ & $1.63 a$ \\
\hline Loamy & $123 a$ & $176 a$ & $9554 b$ & $379 b$ & $125 a$ & $78.5 b$ & $9.19 b$ & $6.57 a$ & $2.19 \mathrm{~b}$ \\
\hline$P$-value & $* * *$ & * & $* * *$ & $* * *$ & $* * *$ & $* * *$ & $* * *$ & $* * *$ & $* *$ \\
\hline \multicolumn{10}{|l|}{ Fertilization } \\
\hline No fertilization & $231 a$ & $186 a$ & $7012 a$ & $309 a$ & $254 a$ & $68.9 a$ & $6.06 a$ & $8.86 a$ & $1.78 a$ \\
\hline Fertilization & $203 a$ & $198 a$ & $8398 b$ & $309 a$ & $234 a$ & $76.8 b$ & $6.98 b$ & $12.8 b$ & $2.05 b$ \\
\hline$P$-Value & n.s. & n.s. & * & n.s. & n.s. & $* * *$ & * & $* \star *$ & *** \\
\hline \multicolumn{10}{|l|}{ Biochar } \\
\hline Control & $221 a$ & $170 a$ & $7988 a$ & $296 a$ & $239 a$ & $72.1 \mathrm{a}$ & $6.58 b$ & $14.2 b$ & $2.03 c$ \\
\hline Effeco 33:33:33 & $214 a$ & $208 a$ & $7629 a$ & $331 b$ & $241 a$ & $73.8 a$ & $6.14 a$ & $9.23 a$ & $1.80 a$ \\
\hline Effeco 50:50 & $216 a$ & $199 a$ & $7498 a$ & $300 a$ & $251 a$ & $72.5 a$ & $6.09 a$ & $9.13 a$ & $1.91 \mathrm{~b}$ \\
\hline$P$-value & n.s. & n.s. & n.s. & $* * *$ & n.s. & n.s. & * & $* * *$ & $* * *$ \\
\hline \multicolumn{10}{|l|}{ INTERACIONS $P$-values } \\
\hline Soil class $\times$ Fertilization & n.s. & n.s. & n.s. & $* * *$ & ** & n.s. & n.s. & $* * *$ & n.s. \\
\hline Soil class $\times$ Biochar & n.s. & n.s. & n.s. & n.s. & n.s. & n.s. & *** & $* * *$ & n.s. \\
\hline Fertilization $\times$ Biochar & * & n.s. & n.s. & $\star *$ & $* * *$ & $* * *$ & $* * *$ & $* * *$ & $* * *$ \\
\hline Soil class $\times$ Fertilization $\times$ Biochar & ** & n.s. & ** & n.s. & $* * *$ & * & $* * *$ & $* * *$ & $* * *$ \\
\hline
\end{tabular}

n.s. - non-significant; $* \mathrm{P}<0.05 ; * * \mathrm{P}<0.01 ; * * * \mathrm{P}<0.001$

Different letters $(\mathrm{a}, \mathrm{b})$ between lines indicate that treatment means are significantly different at $P<0.05$ according to LSD test. 
Table 6. Correlation coefficients between contents of total and available macro and microelements

\begin{tabular}{|c|c|c|c|c|c|c|c|c|c|}
\hline & $P$ & K & $\mathrm{Ca}$ & $\mathrm{Mg}$ & $\mathrm{Fe}$ & $\mathrm{Mn}$ & $\mathrm{Cu}$ & $\mathrm{Zn}$ & $\mathrm{Ni}$ \\
\hline$P$ & 1.000 & 0.188 & $-0.779^{* * *}$ & $-0.799^{* * * *}$ & $0.974^{* * * *}$ & $-0.737^{* * *}$ & $-0.849^{* * *}$ & $0.446^{*}$ & $-0.735^{\star * *}$ \\
\hline K & & 1.000 & -0.252 & -0.163 & 0.168 & 0.258 & -0.207 & 0.346 & -0.128 \\
\hline $\mathrm{Ca}$ & & & 1.000 & $0.485^{\star}$ & $-0.671^{* *}$ & $0.467^{*}$ & $0.470^{*}$ & $-0.622^{* *}$ & $0.480^{*}$ \\
\hline $\mathrm{Mg}$ & & & & 1.000 & $-0.850^{* * *}$ & $0.709^{* * * *}$ & $0.904^{* * * *}$ & -0.412 & $0.739^{*+* t}$ \\
\hline $\mathrm{Fe}$ & & & & & 1.000 & $-0.759^{* * *}$ & $-0.928^{* *+*}$ & 0.371 & $-0.787^{* * *}$ \\
\hline $\mathrm{Mn}$ & & & & & & 1.000 & $0.757^{* * *}$ & 0.007 & $0.732^{* * *+}$ \\
\hline $\mathrm{Cu}$ & & & & & & & 1.000 & -0.248 & $0.843^{*+*+}$ \\
\hline $\mathrm{Zn}$ & & & & & & & & 1.000 & -0.011 \\
\hline $\mathrm{Ni}$ & & & & & & & & & 1.000 \\
\hline
\end{tabular}

$* \mathrm{P}<0.05 ; * * \mathrm{P}<0.01 ; * * * \mathrm{P}<0.001$

were proven e.g. between the total $\mathrm{Ca}$ and available $\mathrm{Mg}, \mathrm{Mn}, \mathrm{Cu}$ a Ni.

\section{Quantity and quality of soil organic matter}

The indicators of soil organic matter and humus are shown in the Table 7. The statistically significant differences of the monitored paramaters were found in dependence on the soil class, which corresponds with the present knowledge [Polláková 2010]. The following were detected in the loamy soil: a higher extractability of humus substances (HS), a higher content of $\mathrm{C}_{\text {org }}$, a higher quality and stability of humus. In contrast, a higher content of $\mathrm{HS}$ from $\mathrm{C}_{\text {org }}$, a higher level of humification, and also a lower quality and stability of humus were detected in the sandy soil. Fertilization is a factor which has an impact on the changes in soil organic matter [Šimanský 2015] through the management of transformation processes in soil [Polláková 2010]. In our experiments, fertilization significantly decreased the extractability of humic acids (HA), the total quantity of $\mathrm{HS}$ from $\mathrm{C}_{\text {org }}$, the level of humification and worsened the humus quality. The application of biochar changed the parameters of soil organic

Table 7. Quantity and quality of soil organic substance and humus

\begin{tabular}{|c|c|c|c|c|c|c|c|c|c|}
\hline \multirow{2}{*}{ Factors } & $\mathrm{C}_{\text {org }}$ & HS & $\mathrm{HA}$ & FA & $\mathrm{C}_{\mathrm{HS}}$ & $\mathrm{C}_{\mathrm{HA}}$ & $\mathrm{C}_{\mathrm{FA}}$ & $\mathrm{C}_{\mathrm{HA}}: \mathrm{C}_{\mathrm{FA}}$ & $Q_{H S}$ \\
\hline & \multicolumn{4}{|c|}{$\mathrm{g} \mathrm{kg}^{-1}$} & \multicolumn{3}{|c|}{$\%$ from $\mathrm{C}_{\text {org }}$} & & \\
\hline \multicolumn{10}{|l|}{ Soil class } \\
\hline Sandy & $10.0 \mathrm{a}$ & $5.11 \mathrm{a}$ & $3.44 a$ & $1.67 a$ & $49.9 b$ & $31.9 b$ & $15.2 b$ & $2.11 \mathrm{a}$ & $5.52 b$ \\
\hline Loamy & $18.6 b$ & $6.44 b$ & $4.44 b$ & $1.99 b$ & $34.8 \mathrm{a}$ & $24.0 a$ & $10.8 a$ & $2.31 \mathrm{~b}$ & $3.86 a$ \\
\hline$P$-value & $* * *$ & $* * *$ & $* * *$ & $* * *$ & 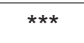 & *** & $* * *$ & * & $* \star *$ \\
\hline \multicolumn{10}{|l|}{ Fertilization } \\
\hline No fertilization & $1.47 a$ & $5.94 a$ & $4.17 \mathrm{~b}$ & $1.77 a$ & $42.8 b$ & $30.0 \mathrm{~b}$ & $12.8 a$ & $2.44 \mathrm{~b}$ & $4.69 a$ \\
\hline Fertilization & $1.39 a$ & $5.61 a$ & $3.71 \mathrm{a}$ & $1.89 a$ & $38.8 \mathrm{a}$ & $25.8 a$ & $13.3 a$ & $1.97 a$ & $4.69 a$ \\
\hline$P$-Value & n.s. & n.s. & $* *$ & n.s. & $* * *$ & $* * *$ & n.s. & $* * *$ & n.s. \\
\hline \multicolumn{10}{|l|}{ Biochar } \\
\hline Control & $1.24 a$ & $6.05 a$ & $4.24 b$ & $1.81 a b$ & $44.6 b$ & $31.4 b$ & $13.1 a b$ & $2.42 b$ & $4.78 b$ \\
\hline Effeco 33:33:33 & $1.51 \mathrm{~b}$ & $5.59 a$ & 3.89ab & $1.69 a$ & $39.1 \mathrm{a}$ & $26.8 a$ & $12.3 a$ & $2.32 b$ & $4.71 \mathrm{ab}$ \\
\hline Effeco 50:50 & $1.56 \mathrm{~b}$ & $5.67 a$ & $3.69 a$ & $2.00 \mathrm{~b}$ & $38.8 \mathrm{a}$ & $25.5 a$ & $13.6 b$ & $1.88 a$ & $4.58 a$ \\
\hline$P$-value & $* * *$ & n.s. & * & * & *** & $* * *$ & * & *** & * \\
\hline \multicolumn{10}{|l|}{ INTERACIONS $P$-values } \\
\hline Soil class $\times$ Fertilization & n.s. & n.s. & n.s. & n.s. & n.s. & ** & n.s. & n.s. & n.s. \\
\hline Soil class $\times$ Biochar & n.s. & * & n.s. & $* * *$ & n.s. & n.s. & ** & $* * *$ & * \\
\hline Fertilization $\times$ Biochar & $* \star * *$ & ** & $* * *$ & * & $* * *$ & *** & n.s. & ** & *** \\
\hline Soil class $\times$ Fertilization $\times$ Biochar & *** & ** & *** & $* *$ & *** & *** & ** & *** & *** \\
\hline
\end{tabular}

n.s. - non-significant; $* \mathrm{P}<0.05 ; * * \mathrm{P}<0.01 ; * * * \mathrm{P}<0.001$

Different letters $(\mathrm{a}, \mathrm{b})$ between lines indicate that treatment means are significantly different at $P<0.05$ according to LSD test. 
substances in a statistically significant way. The Effeco 50:50 biochar decreased the extractability of HA on average by $13 \%$ compared with the control treatment. After the application of both biochars, the content of $\mathrm{C}_{\text {org }}$ rose by $22 \%$ and by $26 \%$ in comparison with the control tretment, which confirms the published data about the ability of biochar to sequester carbon in soils [Agegnehu et al. 2016, Cross et al. 2016]. The degree of humification was decreased by $15 \%$ and $19 \%$ compared with the control treatment, which was reflected in the degradation of humus quality. Of course, this is the effect that occurred following the first year after application. This phenomenon is not unusual because if the organic substances are applied into soil, the balance in soil is violated [Zaujec and Šimanský 2006]. The fundamental question is how this process will continue in the following years. However, the human intervention as well as the climatic factors, will play the decisive role. All the monitored parameters were changed as a result of the mutual impact fertilization $\mathrm{x}$ biochar, but also of all three monitored factors (Table 7).

\section{Soil physical properties}

The sandy soils compared with the loamy soils are characterized by higher levels of bulk density (Fulajtár 2006). In our experiment, the levels of the bulk density $\left(\rho_{d}\right)$ were in the range from 1.10 to 1.54 t.m $\mathrm{m}^{-3}$ in the sandy soil and from 1.08 to $1.50 \mathrm{t}^{\mathrm{m}} \mathrm{m}^{-3}$ in the loamy soil. In any case, the levels did not exceed the critical values, which would indicate the compaction of both soils. The fertilization mainly by the manures, which have lower weight, has the essential impact on the decrease of this parameter [Šimanský et al. 2018]. Additionally, biochar has lower volume weight than soil; therefore, it can participate in the decrease of bulk density of soils, and more significant effect is detected predominantly in the sandy soils, rather than in the loamy soils or clayey soils [Glab et al. 2016]. In our experiments, the average values $\rho_{\mathrm{d}}$ were not influenced by any of the monitored factors or their interactions (Table 8). The fact that the biochar did not decrease $\rho_{\mathrm{d}}$ significantly can be explained that it was applied as granulate which gets harder into the contact with the soil particles, and therefore its impact on some soil properies is being extended on the one hand, on the other hand, its positive impact is detained. The total porosity (TP) is also related to the $\rho_{\mathrm{d}}$ values. The total porosity under $38 \%$ and under $45 \%$ in the sandy and loamy soils indicates the soil compaction (Fulajtár 2006). In our experiments, the average values in both soil classes did not fall under these values, but also we

Table 8. Bulk density, porosity and air characteristcs

\begin{tabular}{|c|c|c|c|c|c|c|c|}
\hline \multirow{2}{*}{ Factors } & $\rho_{d}$ & TP & Ps & $\mathrm{Pn}$ & $\mathrm{Pc}$ & VAM & VA \\
\hline & $\mathrm{t} \mathrm{m}^{-3}$ & \multicolumn{6}{|c|}{$\%$} \\
\hline \multicolumn{8}{|l|}{ Soil classes } \\
\hline Sandy & $1.32 \mathrm{a}$ & $47.7 a$ & $30.9 a$ & $16.9 b$ & $24.4 a$ & $31.7 b$ & $19.8 b$ \\
\hline Loamy & $1.34 \mathrm{a}$ & $47.5 a$ & $35.3 b$ & $12.4 a$ & $31.6 b$ & $25.9 a$ & $13.7 \mathrm{a}$ \\
\hline P-value & n.s. & n.s. & $* * *$ & $* * *$ & $* * *$ & $* * *$ & $* * *$ \\
\hline \multicolumn{8}{|l|}{ Fertilization } \\
\hline No fertilization & $1.32 a$ & $47.8 a$ & $32.7 a$ & $15.3 a$ & $27.6 a$ & $29.8 a$ & $17.2 \mathrm{a}$ \\
\hline Fertilization & $1.33 a$ & $47.4 a$ & $33.5 a$ & $13.9 a$ & $28.4 a$ & $27.7 a$ & $16.3 a$ \\
\hline$P$-Value & n.s. & n.s. & n.s. & n.s. & n.s. & n.s. & n.s. \\
\hline \multicolumn{8}{|l|}{ Biochar } \\
\hline Control & $1.34 a$ & $46.9 a$ & $32.8 a$ & $14.4 a$ & $28.2 a$ & $28.6 a$ & $16.0 \mathrm{a}$ \\
\hline Effeco 33:33:33 & $1.31 \mathrm{a}$ & $48.3 a$ & $33.2 a$ & $15.2 a$ & $27.9 a$ & $29.6 a$ & $17.5 a$ \\
\hline Effeco 50:50 & $1.33 a$ & $47.6 a$ & $33.4 a$ & $14.2 \mathrm{a}$ & $28.0 a$ & $28.2 a$ & $16.7 a$ \\
\hline$P$-value & n.s. & n.s. & n.s. & n.s. & n.s. & n.s. & n.s. \\
\hline \multicolumn{8}{|l|}{ INTERACIONS P-values } \\
\hline Soil classes $\times$ Fertilization & n.s. & n.s. & *** & * & ** & n.s. & * \\
\hline Soil classes $\times$ Biochar & n.s. & n.s. & n.s. & n.s. & n.s. & n.s. & n.s. \\
\hline Fertilization $\times$ Biochar & n.s. & n.s. & $* * *$ & ** & $* * *$ & n.s. & * \\
\hline Soil classes $\times$ Fertilization $\times$ Biochar & n.s. & n.s. & $* * *$ & ** & $* * *$ & n.s. & ** \\
\hline
\end{tabular}

n.s. - non-significant; $* \mathrm{P}<0.05 ; * * \mathrm{P}<0.01 ; * * * \mathrm{P}<0.001$

Different letters $(\mathrm{a}, \mathrm{b})$ between lines indicate that treatment means are significantly different at $P<0.05$ according to LSD test. 
did not record any significant differences between the soil classes. Similarly, neither fertilization nor the biochar application had an effect on TP. Many studies point out the favourable impact of biochar on TP [Omondi et al. 2016, Aktison et al. 2010, Igaz et al. 2018]. In our case, it can be caused by the slow decomposition of biochar particles and its different impact on the different studied soil classes. We also monitored the different energy categories of soil pores. The soil class had the statistically significant effect on the volume of semi-capillary, non-capillary and capillary pores (Table 8). However, the individual categories of soil pores were not influenced by fertlization and biochar application. In the process of evaluation of soil pores redistribution, individually in each soil class, only the effect of biochar was studied. Thus, the individual categories of soil pores were statistically significantly changed as a result of biochar application. The higher dose was used, the higher volume of capillar pores occured, and this effect was more evident in the sandy than loamy soil [Šimanský et al. 2019]. The similar results were also published by Omondi et al. [2016] and Aktison et al. [2010]. The considerable interactions occurred in all energy categories of pores, monitored in soil class $\times$ fertilization combination, as well as fertilization $\times$ biochar and in combination of all factors.
The hydro-physical parameters were statistically significantly dependent on the soil class (Table 9), which correlates with the published data, where the particle-size distribution is considered to be one of the most important factors accountable for the regulation of soil water regime [Fulajtár 2006, Fernández-Ugalde et al. 2009, Kotorová and Šoltýsová 2011, Mati et al. 2011]. In the loamy soil, the values of momental water content in soil, capillary absorbability, maximal capillary capacity, retention water capacity, the point of reduced water availability, lento-capillary point and the reserves of the utilizable water were higher by $36 \%, 16 \%, 21 \%, 30 \%, 24 \%, 44 \%, 24 \%$ and $30 \%$ than in the sandy soil. Only the values of point of reduced water availability and lento-capillary point were increased statistically significantly by fertilization. The effect of applied biochar on the studied hydro-physical properties was not statistically significant, although the trend of rise was detected. As we have mentioned above, this could be caused by the evaluation of these factors in the different soil classes. The explanation is that if the biochar effect is evaluated individually in the frame of the particular soils, then the positive effect of biochar on the improvement of soil water regime is usually evident [Igaz et al. 2018, Peake et al. 2014]. According to Mukherjee and Lal [2013], the improvement of water retention in soil

Table 9. Hydro-physical characteristics

\begin{tabular}{|c|c|c|c|c|c|c|c|}
\hline \multirow{2}{*}{ Factors } & $\Theta$ & $\Theta_{C A}$ & $\Theta_{M C W C}$ & $\Theta_{\mathrm{ZD}}$ & $\Theta v$ & $\Theta p$ & Wv \\
\hline & \multicolumn{7}{|c|}{$\%$} \\
\hline \multicolumn{8}{|l|}{ Soil class } \\
\hline Sandy & $15.9 a$ & $32.6 a$ & $27.9 a$ & $19.2 a$ & $6.10 a$ & $18.4 a$ & $9.84 a$ \\
\hline Loamy & $21.6 b$ & $37.7 b$ & $33.8 b$ & $23.8 b$ & $8.77 b$ & $22.8 b$ & $12.8 \mathrm{~b}$ \\
\hline$P$-value & $* * *$ & $* * *$ & $* * *$ & $* * *$ & 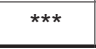 & $* \star *$ & $* * *$ \\
\hline \multicolumn{8}{|l|}{ Fertilization } \\
\hline No fertilization & $17.9 a$ & $34.7 a$ & $30.6 a$ & $20.1 a$ & $6.94 a$ & $20.7 a$ & $11.0 a$ \\
\hline Fertilization & $19.6 \mathrm{~b}$ & $35.6 a$ & $31.1 \mathrm{a}$ & $21.8 b$ & $7.93 b$ & $20.5 a$ & $11.7 a$ \\
\hline P-Value & $* *$ & n.s. & n.s. & * & $* * *$ & n.s. & n.s. \\
\hline \multicolumn{8}{|l|}{ Biochar } \\
\hline Control & 18.3a & $34.9 a$ & $30.8 a$ & $21.4 a$ & 7.31a & $20.8 a$ & $11.0 a$ \\
\hline Effeco 33:33:33 & $18.7 a$ & $35.1 \mathrm{a}$ & $30.8 a$ & $21.5 a$ & $7.39 a$ & $20.5 a$ & $11.3 a$ \\
\hline Effeco 50:50 & $19.4 a$ & $35.5 a$ & $30.9 a$ & $21.5 a$ & 7.60 & $20.4 a$ & $11.7 a$ \\
\hline$P$-value & n.s. & n.s. & n.s. & n.s. & n.s. & n.s. & n.s. \\
\hline \multicolumn{8}{|l|}{ INTERACIONS P-values } \\
\hline Soil class $\times$ Fertilization & n.s. & *** & ** & n.s. & $* * *$ & *** & n.s. \\
\hline Soil class $\times$ Biochar & $*$ & n.s. & n.s. & n.s. & n.s. & n.s. & * \\
\hline Fertilization $\times$ Biochar & *** & *** & *** & *** & n.s. & $* *$ & *** \\
\hline Soil class $\times$ Fertilization $\times$ Biochar & ** & *** & *** & $* * *$ & n.s. & *** & ** \\
\hline
\end{tabular}

n.s. - non-significant; ${ }^{*} \mathrm{P}<0.05 ; * * \mathrm{P}<0.01 ; * * * \mathrm{P}<0.001$

Different letters $(\mathrm{a}, \mathrm{b})$ between lines indicate that treatment means are significantly different at $P<0.05$ according to LSD test. 
after the supply of biochar can be monitored in sandy soils, which have a large content of macropores; however, this effect is usually lower in the soils of higher clay content. If the combinations of factors on the change of hydro-physical properties were studied, then the statistically significant effects were detected in the fertilization $\mathrm{x}$ biochar combinations, and also the combination of all factors (Table 9). The water content in soil is closely related to the air content in soil because the pores are normally filled with water and air. The considerable differences in the momental air content (VAM) were found olny in the dependence on the soil class. Other factors, such as fertilization or biochar did not have the radical impact on change VAM. Moreover, the values of the minimal air content were not influenced by either fertilization or biochar application. These values varied in the optimal interval in the evaluation of all factors, i.e. from $10 \%$ to $20 \%$ [Fulajtár 2006].

The soil structure was affected by the whole complex of the external and internal factors [Amézketa 1999, Bronick and Lal 2005]. The significant effect was caused by particle-size distribution of both soils [Wiseman and Puttmann 2006]. The higher the sand content is, the worse stability of soil structure, and conversely, a higher clay content increases the stability of soil aggregates [Polláková et al. 2018]. Indeed, this is also reflected in the soil structure of the particular soil classes, where a great difference occurs between them, as it is indicated in our results (Tables 10 and 11). In our experiments, the structure of the sandy soil was better than the one characterizing the loamy soil, which is related to more intensive soil management of the vegetable cultivation in loamy soil. Fertilization can have a positive but also a negative impact on the soil structure. The excessive application of the mineral fertilizers can worsen it [Whalen and Chang 2002]. On the other hand, the application of manure can improve it [Munkholm et al. 2002]. In our case, the values of MWDd in both soil classes were significantly decreased as a result of fertilization; however, the vulnerability of soil structure was also decreased as the effect of fertilization. Biochar improves the structural condition [Lu et al. 2014, Obia et al. 2016, Šimanský et al. 2016], but the biochar effect itself also depends on many other factors, such as the biochar type and its properties, the size of its particles, or their ability to react with the soil particles in soil [Šimanský et al. 2016]. In our experiments, the applied biochar had a positive impact on the content of $\mathrm{WSA}_{\text {ma }}$ 0.5-3 mm and MWDw (Table 11). The fractions of WSA were not changed significantly as a result of the applied biochar (Table 10), which can be explained by the biochar granulation and its different application into soil. For example, in the loamy soil, the biochar granules became a part of

Table 10. Proportion of individual fractions of water-stable aggregates

\begin{tabular}{|c|c|c|c|c|c|c|c|}
\hline \multirow{2}{*}{ Factors } & $>5$ & $5-3$ & $3-2$ & $2-1$ & $1-0.5$ & $0.5-0.25$ & $<0.25$ \\
\hline & \multicolumn{7}{|c|}{$\mathrm{mm}$} \\
\hline \multicolumn{8}{|l|}{ Soil class } \\
\hline Sandy & $2.19 a$ & $2.90 a$ & $5.02 a$ & $8.31 b$ & $32.3 b$ & $32.5 a$ & $16.7 a$ \\
\hline Loamy & $7.15 b$ & $4.27 a$ & $4.06 a$ & $4.04 a$ & $14.3 a$ & $34.2 a$ & $46.8 \mathrm{~b}$ \\
\hline$P$-value & $* * *$ & n.s. & n.s. & $* * *$ & $* * *$ & n.s. & $* * *$ \\
\hline \multicolumn{8}{|l|}{ Fertilization } \\
\hline No fertilization & $4.41 a$ & $3.82 a$ & 4.63a & $6.42 a$ & $21.9 a$ & $34.7 a$ & $30.1 a$ \\
\hline Fertilization & $4.93 a$ & $3.35 a$ & $4.46 a$ & $5.92 a$ & $24.7 a$ & $32.0 a$ & $33.5 a$ \\
\hline P-Value & n.s. & n.s. & n.s. & n.s. & n.s. & n.s. & n.s. \\
\hline \multicolumn{8}{|l|}{ Biochar } \\
\hline Control & $3.68 a$ & $2.79 a$ & $4.05 a$ & $4.98 a$ & $20.5 a$ & $35.2 a$ & $28.9 a$ \\
\hline Effeco 33:33:33 & $6.23 a$ & $5.13 a$ & $5.16 a$ & $6.62 a$ & $23.0 a$ & $30.9 a$ & $38.1 \mathrm{a}$ \\
\hline Effeco 50:50 & $4.10 a$ & $2.84 a$ & $4.42 a$ & $6.92 a$ & $26.5 a$ & $34.0 a$ & $28.4 a$ \\
\hline$P$-value & n.s. & n.s. & n.s. & n.s. & n.s. & n.s. & n.s. \\
\hline \multicolumn{8}{|l|}{ INTERACIONS P-values } \\
\hline Soil class $\times$ Fertilization & n.s. & n.s. & n.s. & n.s. & n.s. & n.s. & n.s. \\
\hline Soil class $\times$ Biochar & n.s. & n.s. & n.s. & n.s. & n.s. & n.s. & n.s. \\
\hline Fertilization $\times$ Biochar & n.s. & n.s. & n.s. & n.s. & * & n.s. & n.s. \\
\hline Soil class $\times$ Fertilization $\times$ Biochar & n.s. & n.s. & n.s. & n.s. & n.s. & n.s. & n.s. \\
\hline
\end{tabular}

n.s. - non-significant; $* \mathrm{P}<0.05 ; * * \mathrm{P}<0.01 ; * * * \mathrm{P}<0.001$

Different letters $(\mathrm{a}, \mathrm{b})$ between lines indicate that treatment means are significantly different at $P<0.05$ according to LSD test. 
Table 11. Parameters of soil structure

\begin{tabular}{|c|c|c|c|c|c|c|}
\hline \multirow{2}{*}{ Factors } & $W A_{m a}$ & $\mathrm{WSA}_{\mathrm{ma}} 0.5-3$ & MWDd & MWDw & \multirow{2}{*}{ Kv } & \multirow{2}{*}{$\mathrm{K}$} \\
\hline & \multicolumn{4}{|c|}{$\mathrm{mm}$} & & \\
\hline \multicolumn{7}{|l|}{ Soil classe } \\
\hline Sandy & $83.3 b$ & $45.7 \mathrm{~b}$ & $0.75 a$ & $0.62 a$ & $1.22 \mathrm{a}$ & $0.91 a$ \\
\hline Loamy & $53.2 a$ & $22.4 \mathrm{~s}$ & $2.74 b$ & $0.76 a$ & $4.28 b$ & $1.14 b$ \\
\hline$P$-value & $* * *$ & $* * *$ & *** & n.s. & $* * *$ & *** \\
\hline \multicolumn{7}{|l|}{ Fertilization } \\
\hline No fertilization & $69.9 a$ & $32.0 a$ & $1.88 \mathrm{~b}$ & $0.69 a$ & $3.15 b$ & $1.00 a$ \\
\hline Fertilization & $66.5 a$ & $35.1 \mathrm{a}$ & $1.61 \mathrm{a}$ & $0.70 a$ & $2.35 a$ & $1.05 a$ \\
\hline$P$-Value & n.s. & n.s. & *** & n.s. & * & n.s. \\
\hline \multicolumn{7}{|l|}{ Biochar } \\
\hline Control & $71.1 \mathrm{a}$ & $29.5 a$ & 1.73ab & $0.59 a$ & $3.27 a$ & $1.01 \mathrm{a}$ \\
\hline Effeco 33:33:33 & $61.9 a$ & $34.7 a b$ & $1.85 b$ & $0.83 b$ & $2.46 a$ & $1.00 a$ \\
\hline Effeco 50:50 & $71.6 a$ & $37.9 b$ & $1.65 a$ & $0.67 a b$ & $2.53 a$ & $1.06 a$ \\
\hline$P$-value & n.s. & * & $*$ & * & n.s. & n.s. \\
\hline \multicolumn{7}{|l|}{ INTERACIONS $P$-values } \\
\hline Soil class $\times$ Fertilization & n.s. & n.s. & n.s. & n.s. & n.s. & *** \\
\hline Soil class $\times$ Biochar & n.s. & n.s. & * & n.s. & n.s. & ** \\
\hline Fertilization $\times$ Biochar & n.s. & * & n.s. & * & ${ }^{*}$ & *** \\
\hline Soil class $\times$ Fertilization $\times$ Biochar & n.s. & n.s. & $* * *$ & n.s. & *** & * \\
\hline
\end{tabular}

n.s. - non-significant; $* \mathrm{P}<0.05 ; * * \mathrm{P}<0.01 ; * * * \mathrm{P}<0.001$

Different letters $(\mathrm{a}, \mathrm{b})$ between lines indicate that treatment means are significantly different at $P<0.05$ according to LSD test.

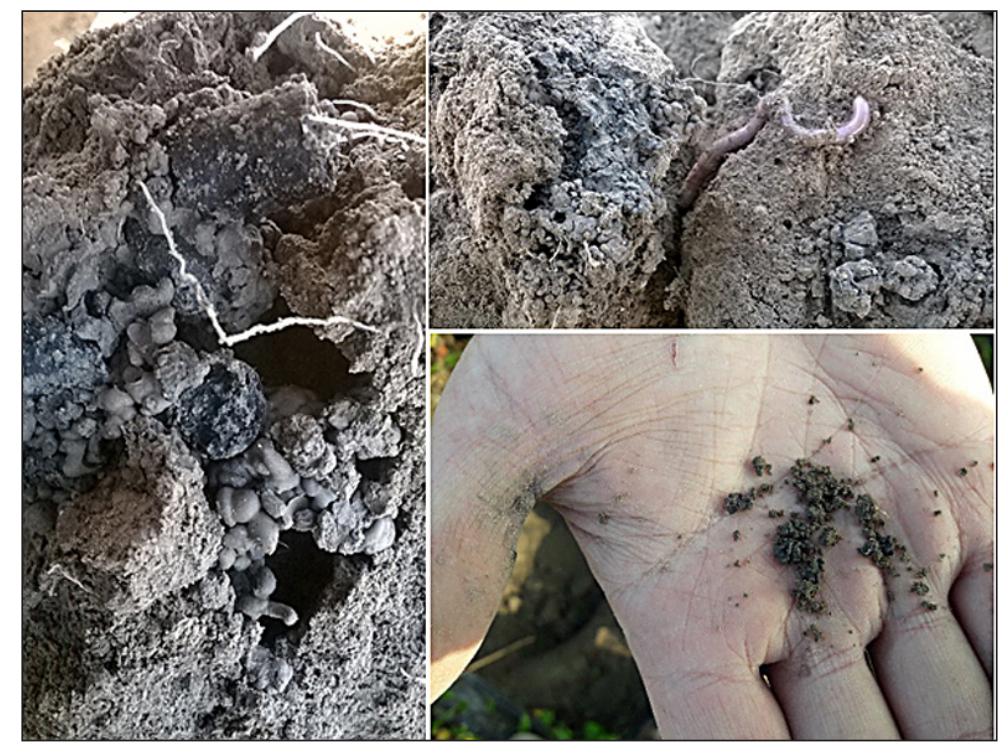

Figure 1. Effect of earthworms in soil with applied biochar - (Earthworms ingest soil and biochar, mixing in their gut)

aggregates via the intesive activity of earthworms (Figure 1). Hence, if the biochar effect was evaluated independently in the loamy soil, the structure was thus significantly improved as a result of this biological formation of aggregates, compared with the sandy soil [Šimanský et al. 2019]. The interesting fact is that no interaction had a significant impact on the individual changes in the fractions of WSA, apart from the effect of the interaction fertilization $x$ biochar on $\mathrm{WSA}_{\mathrm{ma}} 0.5-3 \mathrm{~mm}$.
Only the values of $\mathrm{K}$ were affected significantly by all interactions of the monitored factors.

\section{CONCLUSION}

The results indicated that the the soil class is the most significant factor which has impact on the studied parameters. Fertilization proved to be the factor having a negative impact on the humus 
parameters; on the other hand, it improved the soil sorption. Biochar increased the content of organic matter in soil, also its positive environmental effect on the retention and immobilization of harmful element was demonstrated, as well as its positive effect on the soil structure. The highest frequency of interactions among the monitored factors on the change of soil properties was recorded in the fertilization $\times$ biochar combination, and also soil class $\times$ fertilization $\times$ biochar. We assume that in the following period, the application of biochar at the beginning of experiment will lead to a more significant improvement, predominantly of the parameters of soil humus, nutrient regime and also the physical characteristics. If the biochar is supposed to be a part of the common agricultural practice also in Slovakia, then it is essential to acquire the knowledge about the mutual interactions also with other common agronomical measures, which should be monitored very carefully for a longer period of time.

It is apparent that the research activities in the area of the balance of organic substances in the soils in the Slovak Republic are progressing. Recently, the effects of biochar (as the potential source of organic substances applied into soil after processing of the biological materials) as well as its interactions with the other agronomical factors have also been studied. The results of our experiments in Slovakia could contribute to these attainments, which can support filling the knowledge gaps in this field of study.

\section{Acknowledgements}

This study was supported by the Slovak Grant Agency VEGA, No. 1/0136/17. The authors thank Zdroje Zeme ag., very much for the financial support.

\section{REFERENCES}

1. Agegnehu G., Bass A.M., Nelson P.N., Bird M.I. 2016. Benefits of biochar, compost and biocharcompost for soil quality, maize yield and greenhouse gas emissions in a tropical agricultural soil. Science of the Total Environment, 543, 295-306.

2. Aijun Y., Changle Q., Shusen M., Reardon E.J. 2006. Effects of humus on the environmental activity of mineral-bound $\mathrm{Hg}$ : Influence on $\mathrm{Hg}$ volatility. Applied Geochemistry, 21(3), 446-454.

3. Ajayi A.E., Horn R. 2016. Modification of chemical and hydrophysical properties of two texturally differentiated soils due to varying magnitudes of added biochar. Soil and Tillage Research, 166, 34-44.

4. Amézketa E. 1999. Soil aggregate stability: a review. Journal of Sustainable Agriculture, 14(2-3), $83-151$.

5. Atkinson C.J., Fitzgerald J.D., Hipps N.A. 2010. Potential mechanisms for achieving agricultural benefits from biochar application to temperature soils: a review. Plant and Soil, 337, 1-18.

6. Beusch Ch., Cierjacks A., Bohm J., Mertens M., Bischoff W.A., Filho J.C.A., Kaupenjohann M. 2019. Biochar vs. clay: Comparison of their effects on nutrient retention of a tropical Arenosol. Geoderma, 337, 524-535.

7. Biederman L.A., Harpole W.S. 2013. Biochar and its effects on plant productivity and nutrient cycling: a meta-analysis. GCB Bioenergy, 5, 202-214.

8. Bronick C.J., Lal R. 2005. The soil structure and land management: a review. Geoderma, 124, 3-22.

9. Cross A., Zwart K., Shackley S., Ruysschaert G. 2016. The role of biochar in agricultural soils. In: Shackley S., Ruysschaert G., Zwart K., Glaser B. (Eds), Biochar in European Soils and Agriculture. Routledge, London, New York, pp. 73-98.

10. Dziadowiec H., Gonet S.S. 1999a. Estimation of soil organic carbon by Tiurin's method. Methodical guide-book for soil organic matter studies (in polish). 120, 7-8.

11. Dziadowiec H., Gonet S.S. 1999b. Estimation of fractional composition of soil humus by KononovaBielcikova's method. Methodical guide-book for soil organic matter studies (in polish). 120, 31-34.

12. El-Naggar A., Lee S.S., Awad Y.M., Yang X., Ryu C., Rizwan M., Rinklebe J., Tsang D.C., Ok Y.S. 2018. Influence of soil properties and feedstocks on biochar potential for carbon mineralization and improvement of infertile soils. Geoderma, 332, 100-108.

13. El-Naggar A., Lee S.S., Rinklebe J., Farooq M., Song H., Sarmah A.K., Zimmerman A.R., M., Shaheen S.M., Ok, Y.J. 2019. Biochar application to low fertility soils: A review of current status, and future prospects. Geoderma, 337, 536-557.

14. Evangelou M.W.H., Brem A., Ugolini F., Abiven S., Schulin R. 2014. Soil application of biochar produced from biomass grown on trace element contamined land. Journal of Environmental Management, 146, 100-106.

15. Fernández-Ugalde O., Virto I., Bescansa P., Imaz M.J., Enrique A., Karlen D.L. 2009. No-tillage improvement of soil physical quality in calcareous, degradation-prone, semiarid soils. Soil \& Tillage Research, 106, 29-35.

16. Fischer D., Glaser B. 2012. Synergisms between compost and biochar for sustainable soil ameliora- 
tion. In: Kumar S. (Ed), Management of Organic Waste, Tech Europe, Rijeka, pp. 167-198.

17. Fulajtár E. 2006. Soil physical properties. SSCRI, Bratislava, (in Slovak).

18. Głąb T., Palmowska J., Zaleski T., Gondek K. 2016. Effect of biochar application on soil hydrological properties and physical quality of sandy soil. Geoderma, 281, 11-20.

19. Glaser B. 2007. Prehistorically modified soils of central Amazonia: a model for sustainable agriculture in the twenty-first century. Philosophical Transactions of the Royal Society of London Series B: Biological Sciences, 362, 187-196.

20. Green Report. 2014. Green Report for 2013. Národné pol'nohospodárske a potravinárke centrum, Bratislava, (in Slovak).

21. Greenland D.J., Rimmer D., Payne D. 1975. Determination of the structural stability class of English and Welsh soil, using a water coherence test. Journal of Soil Science, 26(2), 294-303.

22. Hanes J., 1999. Analyzes of sorptive characteristics. SSCRI, Bratislava, (in Slovak).

23. Heitkötter J., Marschner B. 2015. Interactive effects of biochar ageing in soils related to feedstock, pyrolysis temperature, and historic charcoal production. Geoderma, 245-246, 56-64.

24. Horák J., Kondrlová, E., Igaz, D., Šimanský V., Felber R., Lukac M., Balashov E.V., Buchkina N.P., Rizhiya E.Y., Jankowski M. 2017. Biochar and biochar with N-fertilizer affect soil N2O emission in Haplic Luvisol. Biologia, 72(9), 995-1001.

25. Hraško J., Bedrna Z. 1988. Applied Soil Science. Príroda, Bratislava, (in Slovak).

26. Hraško J., Červenka L., Facek Z., Komár J., Něměček J., Pospíšil J., Sirový V. 1962. Soil analyses. SVPL, Bratislava, (in Slovak).

27. Hrivňáková K., Makovníková J., Barančíková G., Bezák P., Bezáková Z., Dodok R., Grečo V., Chlpík J., Kobza J., Lištjak M., Mališ J., Píš V., Schlosserová J., Slávik O., Styk J., Širáň M. 2011. Uniform methods of soil analyses. VÚPOP, Bratislava, (in Slovak).

28. Chintala R., Owen R., Kumar S., Schumacher T.E., Malo D. 2014. Biochar impacts on denitrification under different soil water contents. World Congress of Soil Science, 6, 157-157.

29. Ibrahim E.A., Ramadan W.A. 2015. Effect of zinc foliar spray alone and combined with humic acid or/and chitosan on growth, nutrient elements content and yield of dry bean (Phaseolus vulgaris L.) plants sown at different dates. Scientia horticulturae, 184(5), 101-105.

30. Igalavithana A.D., Lee S.E., Lee Y.H., Tsang D.C.W., Rinklebe J., Kwon E.E., Ok Y.S. 2017. Heavy metal immobilization and microbial community abundance by vegetable waste and pine cone biochar of agricultural soils. Chemosphere, 174, 593-603.

31. Igaz D., Šimanský V., Horák J., Kondrlová E., Domanová J., Rodný M., Buchkina N.P. 2018. Can a single dose of biochar affect selected soil physical and chemical characteristics? Journal of Hydrology and Hydromechanics, 66(4), 421-428.

32. Jeffery S., Abalos D., Prodana M., Bastos A.C., van Groenigen J.W., Hungate B.A., Verheijen F. 2017. Biochar boosts tropical but not temperate crop yields. Environmental Research Letters, 12, 053001.

33. Jurčová O., Bielek P. 1997. Resources and losses of soil organic matter and their balance. Humic Substances in Environment, (in Slovak), 17-24.

34. Kobza J., Barančíková G., Makovníková J., Pálka B., Styk J., Širáň M. 2017. Current state and development of land degradation processes based on soil monitoring in Slovakia. Agriculture (Pol'nohospodárstvo), 63(2), 74-85.

35. Kotorová D., Šoltysová B. 2011. Physical and chemical properties of heavy soils. Piešt'any: CVRV (in Slovak).

36. Kováčik P. 2014. Principles and methods of plant nutrition. SUA, Nitra, pp. 278. (in Slovak).

37. Laghari M., Mirjat M.S., Z., Fazal S., Xiao B., Hu M., Chen Z., Guo, D. 2015. Effects of biochar application rate on sandy desert soil properties and sorghum growth. Catena, 135, 313-320.

38. Lal R. 2004. Soil carbon sequestration to mitigate climate change. Geoderma, 123, 1-22.

39. Lehmann J., Joseph S. 2015. Biochar for environmental management. Routledge, Taylor and Francis Group, London, New York.

40. Lehmann J., Rillig M.C., Thies J., Masiello C.A., Hockaday W.C., Crowley D. 2011. Biochar effects on soil biota - a review. Soil Biology and Biochemistry, 43, 1812-1836.

41. Linkeš V., Kobza J., Švec M. 1997. Monitoring soil of the Slovak Republic. Výskumný ústav pôdnej úrodnosti, Bratislava, (in Slovak).

42. Lu S.G., Sun F.F., Zong Y.T. 2014. Effect of rice husk biochar and coal fly ash on some physical properties of expansive clayey soil (Vertisol). Catena, 114, 37-44.

43. Mati R., Kotorová D., Gomboš M., Kandra B. 2011. Development of evapotranspiration and water supply of clay-loamy soil on the East Slovak Lowland. Agricultural Water Management, 98, 1133-1140.

44. Mia S., Van Groenigen J.W., Van de Voorde T.F.J., Oram N.J., Bezemer T.M., Mommer L., Jeffery S. 2014. Biochar application rate affects biological nitrogen fixation in red clover conditional on potassium availability. Agriculture, Ecosystems \& Environment, 191, 83-91. 
45. Mukherjee A., Lal R. 2013. Biochar impacts on soil physical properties and greenhouse gas emissions. Agronomy, 3, 313-339.

46. Munkholm L.J., Schjonning P., Debosz K., Jensen H.E., Christensen B.T. 2002. Aggregate strength and mechanical behaviour of a sandy loam soil under long-term fertilization treatments. European Journal of Soil Science, 53, 129-137.

47. Novak J.M., Busscher W.J., Wats D.W., Laird D.A., Ammenda M.A., Niandou M.A.S. 2009. Short-term CO2 mineralization after additions of biochar and switchgrass to a Typic Kandiudult. Geoderma, 154, 281-288.

48. Obia A., Mulder J., Martinsen V., Cornelissen G., Børresen T. 2016. In situ effects of biochar on aggregation, water retention and porosity in light-textured tropical soils. Soil and Tillage Reseach, 155, 35-44.

49. Olivares F.L., Aguiar N.O., Rosa R.C.C., Canellas L.P. 2015. Substrate bioforticication of combination with foliar sprays of plant growth promoting bacteria and humic substances boosts production of organic tomatoes. Scientia Horticulturae, 183, 100-108.

50. Omondi M.O., Xia X., Nahayo A., Liu X., Korai P.K., Pan G. 2016. Quantification of biochar effects on soil hydrological properties using meta-analysis of literature data. Geoderma, 274, 28-34.

51. Peake L., Freddo A., Reid B.J. 2014. Sustaining soils and mitigating climate change using biochar. In: De Las Heras, A. (Ed.), Sustainability Science and Technology. CRC Press, pp. 109-126.

52. Peretyazhko T., Sposito G. 2006. Reducing capacity of terrestrial humic acids. Geoderma, 137(1-2), 140-146.

53. Polláková N., Šimanský V., Kravka M. 2018. The influence of soil organic matter fractions on aggregates stabilization in agricultural and forest soils of selected Slovak and Czech hilly lands. Journal of Soils and Sediments, 18(8) 2790-2800.

54. Rajkovich S., Enders A., Hanley K., Hyland C., Zimmerman A.R., Lehmann J. 2012. Corn growth and nitrogen nutrition after additions of biochars with varying properties to a temperate soil. Biology and Fertility of Soils, 48(3), 71-284.

55. Rao C.S., Indoria A.K., Sharma K.L. 2017. Effective management practices for improving soil organic matter for increasing crop productivity in rainfed agroecology of India. Current Science, 112, 1497-1504.

56. Szombathová N. 2010. Chemical and physicochemical properties of humic substances of soil as an indicator of anthropogenetic changes in ecosystems (localities of Bab and Dolná Streda). SPU, Nitra, (in Slovak).

57. Šimanský V. 2015. Fertilization and carbon sequestration. Acta fytotechnica et zootechnica, 18(3), 56-62.
58. Šimanský V., Horák J., Igaz D., Balashov E., Jonczak J. 2018. Biochar and biochar with $\mathrm{N}$ fertilizer as a potential tool for improving soil sorption of nutrients. Journal of Soils and Sediments, 18(8), 1432-1440.

59. Šimanský V., Horák J., Igaz D., Jonczak J., Markiewicz M., Felber R., Rizhiya E.Y., Lukac M. 2016. How dose of biochar and biochar with nitrogen can improve the parameters of soil organic matter and soil structure? Biologia, 71(9), 989-995.

60. Šimanský V., Polláková N. 2014. Soil organic matter and sorption capacity under different soil management practices in a productive vineyard. Archives of Agronomy and Soil Science, 60(8), 1145-1154.

61. Šimanský V., Polláková N., Chlpík J., Kolenčík M. 2018. Soil Science. SPU, Nitra, (in Slovak).

62. Šimanský V., Šrank D., Juriga M. 2019. Differences in soil properties and crop yields after application of biochar blended with farmyard manure in sandy and loamy soils. Acta Fytotechnica et Zootechnica, 22(1), 21-25.

63. Šimanský V., Tobiašová E., Chlpík J. 2008. Soil tillage and fertilization of Orthic Luvisol and their influence on chemical properties, soil structure stability and carbon distribution in water-stable macro-aggregates. Soil \& Tillage Research, 100(1-2) 125-132.

64. Teutscherova N., Vazguez E., Santana D., Navas M., Masaguer M.B. 2017. Influence of pruning waste compost maturity and biochars on carbon dynamics in acid soil: Incubation study. European Journal of Soil Biology, 78, 66-74.

65. Vaněk V., Ložek O., Balík J., Pavlíková D., Tlustoš P. 2013. Nutrition of field and garden crops. Profi Press SK, Nitra. pp. 184. (in Slovak).

66. Whalen J.K., Chang C. 2002. Macroaggregate characteristics in cultivated soils after 25 annual manure applications. Soil Science Society of American Journal, 66, 1637-1647.

67. Wiseman C.L.S., Pütmann W. 2006. Interactions between mineral phases in the preservation of soil organic matter. Geoderma. 134, 109-118.

68. Zaujec A., Chlpík J., Nádašský J., Szombathová N., Tobiašová E. 2009. Pedology and basics of geology. SPU, Nitra, (in Slovaka).

69. Zaujec A., Šimanský V. 2006. The effect of biopreparates of plant resudues on soil structure and soil organic matter. SPU, Nitra, (in Slovak).

70.Zlámalová T., Elbl J., Baroň M., Bělíková H., Lampír L., Hlušek J., Lošák T. 2015. Using foliar applications of magnesium and potassium to improve yields and some qualitative parameters of vine grapes (Vitis vinifera L.). Plant Soil Environ, 61(10), 451-457. 